\title{
Extensive Reading in Developing English Competency for Indonesian EFL Learners Majoring in English
}

\author{
Syofia Delfi \\ Riau University, Indonesia \\ e-mail: syofia_delfi@yahoo.com
}

\section{Hamidah Yamat}

State University of Malaysia, Malaysia

\begin{abstract}
:
Extensive reading might develop EFL learners' English competency because in the process of reading, they keep on reading a lot of reading materials and immerse in the language use. This article is based on literature review for a study " a Case Study on Two Indonesian Learners' Extensive Reading in English Experiences towards Developing Reading Competency". This article aims to describe how extensive reading contributes to English competency of EFL learners. The review shows that the contribution of extensive reading is in terms of the context of Indonesian EFL learners, learning language for Indonesian EFL learners, and characteristics and the benefit of extensive reading meet the Indonesian EFL Learners' reading experiences. The more the learners read, the more they acquire the language, and the more they acquire the language, the more they develop their language competency. This process shows how extensive reading contributes to English competency. This review is expected to be meaningful for the study designed.
\end{abstract}

Keywords: extensive reading, English competency, learning language 


\section{Introduction}

Reading English texts has important roles for EFL learners majoring in English since reading is not only as a subject but also as an activity done in studying other English courses. They usually read texts which are interesting for them and they have reasons reading a particular text. Besides, they probably do reading activities out side of the classroom. They may read at any places; at home and at the campus area.

In Indonesia contexts, English is learnt referring to the language learning policy implemented in the curriculum. Language learning policy in Indonesia is based on the legislation in which education systems are controlled and supervised by the government. It is implemented as stated in the curriculum. The core curriculum for whole schools in Indonesia is national curriculum. Some evidences reffering to the language policy in Indonesia reflecting on the language learning. Indonesian is as the national language and English is the first foreign language in which learnt by all Indonesian learners. Indonesia learners learn English as a foreign language indicating that they do not use English in day to day communication; formal or in formal communication. Hence, in the process of learning English they are expected to expose in English. They are also expected to be involved in the context in which the language used. One of the possible activities that the learners do is by doing extensive reading. Their involment to the language exposure through reading based on their interest develops the learners' competence (Hedgcock \& Ferris, 2009)

Indonesian learners should know the term of extensive reading. This is because they have been introduced to extensive reading in their first language that is Indonesian since Senior High School as stated in the curriculum for Indonesian (Bahasa Indonesia). However, the extensive reading that they have done is only through the reading materials in their handbook; as a topic to be discussed in the learning materials (Tukan, 2007). Through extensive reading, their knowledge on vocabulary, various sentence structures, meaning of words, and different forms and functions of words will increase. Gradually, it will develop their competence in the language skills if they keep on doing extensive reading. It is also as one of ways to make Indonesian learners to be active.

Studies have shown the relationship between extensive reading, learning language aspects and language skills for EFL learners (Lee \& Hsu, 2009; Mermelstein, 2014; Edy, 2014). The relationship is in terms of acquiring vocabulary and grammar that develop the learners' language competency. This should be made aware by all Indonesian EFL learners that extensive reading is more than just reading extensively; it helps develop their language competency. It is due to the fact that English is as a foreign language for Indonesian learners. Therefore, this article aims to describe how extensive reading contributes to English competency for Indonesian EFL learners majoring in English. 


\section{Review of Related Theories}

Theories related to this article "Extensive Reading for EFL Learners majoring in English in Developing English Competency" are language learning theory, extensive reading and language competence. Each theories will be discussed in the following section.

\subsection{Language Learning Theory}

Richards \& Rodgers (2007) point out that language learning theory may be provided by the theory of the language; structural view, functional view, and interactional view while learning occurs as a result of experience. The experience may be based on one's prior experience or the experience of others. It may be structured or unstructured, formal or informal, inside or outside of a classroom. A general theory of second language acquisition needs language acquisition by learners. The acquisition is in a variety of characteristics in contexts (Lightbown \& Spada, 2011). Language learning theory relating to this context is second language acquisition (SLA). Krashen (1982) argues that language acquisition is very similar to the process of children used in acquiring first and second languages.

Ellis (2003) defines that second language acquisition (SLA) is as the way in which people learn a language other than their mother tongue, inside or outside of the classroom. Hence, Ellis (2012) claims that SLA is the product of many factors pertaining to the learner and the learning situation. Since learning of second language takes place some time later than the acquisition of the first language, learners should be exposured to the language used. This is in line with the Input Hyphothesis Theory offered by Krashen (1982).

Krashen (1982) discusses the Input Hyphothesis Theory focusing on the context in understanding the language system that learners have not known. The Input Hyphothesis indicates that we acquire by "going for meaning" first, and as a result, we acquire structure. It is expected that learners use more than the linguistic competence to help them understand language, especially in understanding the language aspects that they have not known yet. Hence, Krashen classifies the Hypothesis into three parts; (1) the Input Hypothesis Theory relates to acquisition, (2) We acquire by understanding language that contains structure beyond our current level of competence $(i+1)$. This is done with the help of context or extra-linguistic information, (3) Communication is successful when the input is understood and there is enough of it, " $i+1$ " will be provided automatically, (4) Production ability emerges and it is not taught directly. Krashen (1985) points out that second languages are acquired by receiving comprehensible input; language that is heard/ read and that is slightly ahead of a learners' grammatical knowledge. Consequently, Krashen's emphasizes that second languages are acquired by understanding messages.

In perceiving the meaning of the Input Hypothesis, Gass \& Selinker (1994) claims that input refers to what is available to learners. It can be in spoken and written form to which the learners are exposed. Native speakers make adjustments to their speech and the areas of pronunciation, grammar, and lexicon. These areas are also the areas 
for comprehensibility. An additional factor determining comprehensibility is the ability of non native speaker to contextualize the language by using appropriate vocabulary and linking devices. A study on Comprehensible Input through Extensive Reading has been presented by Wang (2011).

The Input Hypothesis Theory (1982) by Krashen simplifies about understanding the language aspects like vovabulary, grammar, and pronunciation for meaning in acquiring the language. Indonesian EFL students who are not in the environment in which English is used orally, they may involve in the context in which the language can be acquired through reading the use of the language aspects in the reading materials. The Input Hypothesis Theory (1982) by Krashen and Input by Gass \& Selinker (1994) indicate that students may do extensive reading in developing the language competence. The students' understanding about the language aspects make them acquire the language for the process of understanding the reading materials.

Studies on experiences in second language acquisition have been conducted by researchers. Yamat (2012) studied about SLA experiences of three young Malaysian children aged six while attending a mainstream school and living in U.K. It focuses on how they developed an identity while experiencing SLA. The finding of this study indicates that the children acquire the language as they were getting on with their live in their social context. They interacted with the people and their environment. Yamat further claimed that language acquisition may be enhanced by providing a context where the children are able to get opportunities to receive and use the language. The study has given insights to experiences of SLA process of three young Malaysian children. This study recommends similar study in the participants' own country.

Reading has roles for learning and especially for learning the language. Learners will gain the knowledge through reading (Hedge, 2008). Reading is useful for language acquisition since it provides students with reading materials higher or lower than the students' ability (Hammer, 2009). It affects on the students' vocabulary knowledge, grammar, writing, speaking in terms of talking about the idea gained from texts read. It also implies that reading can also affect on listenig since speakers and listeners in discussion about the topic from texts. The more learners acquire the language, the more they will be competent on the language. Lee \& Hsu (2009) emphasize that reading is the source of good writing style because learners can learn vocabulary, syntax and discource structure of the written language.

The role of reading is based the general learning goals for the reading component of an English language course as offered by Hedge (2008). The goals are to be able to read a range of texts in English; to adapt reading style according to range of purposes and apply different strategies (skimming and scanning); to build a knowledge of language (vocabulary and structure) which will facilitate development of greater reading ability. It will build schematic knowledge in order to interpret texts meaningfully; to develop awareness of the structure of written texts in English and to be able to make use of rhethorical structure, discourse features, and cohesive devices in comprehending texts, and to take a critical stance to the content of texts. 
Therefore, doing extensive reading is supposed as an activity to gain the goal in learning English in Indonesia as Krashen (1988) means.

\subsection{Extensive Reading}

Bamford \& Day (2004) point out that readers in extensive reading read a lot of reading materials for information and enjoyment and they choose their own reading materials. Brown (2001) claims that extensive reading is caried out to achieve a general understanding of texts. Although readers read a lot of reading materials, they read for general information and overall meaning. Brown also points out that extensive reading is recognized as pleasure reading. He also claims that readers will stop reading when they think the materials are not interesting or it is too difficult.

Bamford \& Day (1998) explore ten principles of extensive reading: 1) The reading material is easy, (2) A variety of reading material on a wide range of topics is available, (3) Learners choose what they want to read, (4) Learners read as much as possible, (5) Reading speed s usually faster rather than slower, (6) The purpose of reading is usually related to pleasure, information and general understanding, (7) Reading is individual and silent, (8) Reading is own reward, (9) The teacher orients and guides students, (10) The teacher is a role model of a reader.

Extensive reading is good for personal development, therefore, promiscuously and associatively it is good not only for students but also good for teacher. Bamford and Day (1998) point out that the benefit of extensive reading that students who read more will not only become better and more confident readers but they will also improve their reading, writing and listening, and speaking abilities and their vocabulary will get richer, motivation aspects of reading.

Bamford \& Day (1998) claims that reading can be viewed based on number of different activities. The activities refer to sociocultural, physchological, affective, philosophical, educational, and cognitive. Contextually, appropriate meanings in reading mean both semantic and syntactic which are related to words. This should be understandable by readers, especially for readers in which English as a second or as a foreign. Fluent readers recognize words interfered with the construction of meaning. This is due to the fact that reading as a component of general second language proficiency (Brown, 2001).

Hedgcock \& Ferris (2009) conclude the benefit of extensive reading for second language readers into six ways. First, extensive reading improves comprehension skills through practice for background knowledge and reading skills to particular texts. Second, extensive reading develops automaticity through great reading. In the process of reading, learners recognize words as well as vocabulary knowledge, morphology and syntax in which the words occur. Pigada \& Schmitt (2007) enhanced the students' knowlledge about vocabulary in terms of spelling, meaning, and grammatical behavior of words in text. Guo (2012) found that the effect on the use of extensive reading on the improvement of vocabulary aquisition in her study in Taiwan for college students majoring in English. Nwabudike \& Anaso (2013) found that the students of Nigerian-Turkish International College, Kano have high stock of vocabulary although they engaged on extensive reading on their own. To that 
context, extensive reading program was not implemented in Nigerian-Turkish International Colleges, Kano. The students expected that their college implemented extensive reading. Third, extensive reading builds background knowledge by engaging in the texts read. The background knowledge prepares readers to the future reading. Doing extensive reading builds vocabulary and grammar knowledge by acquiring linguistic knowledge through reading.

The fourth benefit of extensive reading is the exposure of the natural use of language in the printed materials. It can make them acquire the language for their progress in the language. Fifth, extensive reading improves productive skills through acquiring the input from reading for the output for productive skills. Guo (2012) also proves that extensive reading has effects on the students' language skills. Nwabudike \& Anaso (2013) specified the skill developed by doing extensive reading was listening. The last use of exstensive reading is to promote students with confidence and motivation. This is because extensive is enjoyable and motivate learners to take on reading on their own in the future. This can build confidence in their own reading skills and their ability to use the second language. Yamashita (2004) found that the students had comfort self-perception reflecting on reading proficiency. It influences the performance in extensive reading.

The benefit of extensive reading has been proven by researchers and teachers. It can not only improve students' reading ability, but it has also been shown to expand knowledge of vocabulary, raise the general level of a language testing, and improve fluency and accuracy in writing. Brown (2001) claims that extensive reading component in conjunction with other focused reading instruction is highly warranted. Yamashita (2008) found in their study that extensive reading improve the students' reading rate or reading strategy and the general language proficiency. Junko (2008) believes that the students' recognition on reading strategy makes them quickly learn to apply the effective strategies to L2 reading and extensive reading is also as the form of acquiring micro level linguistics.

Mermelstein (2014) studied the use of extensive reading in improving EFL learners' reading for non English major in Taiwan. The study proves significantly higher reading level gained by the treatment group. The study suggests that utilizing extensive reading can provide a successful alternative to improve Asian learner's reading levels as well as considering pedagogical suggestion in implementing ER. The practice on extensive reading in this study was only for reading course in which the goal is for comprehension. Therefore, Sarwo Edy suggests make special course for extensive reading in order to enhance the students' reading skills and reading habit. Jang et al (2015) studied the effect of English extensive reading activities on the students' reading proficiency and reading motivation. The study found that extensive reading activities have a positive influence on students' reading proficiency and their intrinsic motivation.

Chen et al (2013) studied the effects of extensive reading of e-books on Taiwanese tertiary level EFL technological students' English reading attitude, reading comprehension, and vocabulary. The study found that extensive reading of e-books facilitates Taiwanese tertiary level EFL technological students' English reading 
attitude, reading comprehension, and vocabulary growth. The finding also indicates that extensive reading via e-books could improve tertiary level EFL students' L2 learning. The experimental group achieved larger gains in reading attitude, comprehension, and vocabulary growth, and their conscious acquisition of the target language was accelerated. The findings suggest that certain tasks used in extensive reading may help development of learners' reading comprehension and vocabulary growth, such as finding out key words/ phrases worth studying in this reading, guessing word meaning from context; connecting the contents of the reading selection to current or past real world events and experiences, finding passages they would like to/ should hear; writing their reflection toward the reading text in the weekly individual reading journals as well as groups' reading work sheet.

Ahmed \& Rajab (2015) investigated the impact of extensive reading on developing second Language (L2) reading comprehension and writing skills among primary school EFL Learners in two Arab countries, Egypt and Saudi Arabia. The study has proven that extensive reading can improve the second Language (L2) reading comprehension and writing skills among primary school EFL learners in two Arab countries, Egypt and Saudi Arabia. The study also proves the role of teachers in terms of engaging in reading and the exposure of young EFL learners to sufficient and suitable materials. Learners have limited chance of L2 interactions outside the classroom boundaries; therefore, they need to be exposed to massive text input. The writers also suggest establishing vision of promoting ER in young learners in order to lead them to gain self-efficacy and self confidence on their academic lives. Therefore, reading as a major L2 skill, needs to be reconsidered in the EFL context in general and in the EFL for young learners in particular. The researchers expect that the study will contribute to a growing compendium of literature aimed at developing a much wider and deeper understanding of the benefits and advantages of EFL enrichment programs in EFL young learners.

The studies about extensive reading show the benefits of extensive reading for EFL/ ESL learners. They are in terms of language competence; language components and language skills, and learners' attitude, motivation, and confidence on learning language generally and specifically on reading. These are as the reflection of characteristics of extensive reading indicating the activities of extensive reading

\subsection{Language Competency}

Competence is in terms of having knowledge about the language aspects and how they are used. The language aspects are vocabulary, grammar: tenses, sound system, pragmatic: language context, and the rule/ structure/ syntax. Brown (2007) points out that competence refers to one's underlying knowledge of system event or fact. Hence, Brown (2007) states that performance is actual production (speaking, writing) or the comprehension (listening, reading) of linguistic form. Language competence in the context of this current study refers to both comprehension and production. Performance looks at actual utterance as well as the learners' knowledge about the language (Ellis, 2010). He also points out that the study of SLA is directed at accounting for learner's competence referring to the investigation how learners perform in using the second language. To the context of this study, the EFL 
learners' competence on English is identified through their performance in using the aspects of the language and how the competence is contributed by extensive reading.

Richards \& Rodgers (2007) believe that competencies describe the students' ability to apply basic and other skills in situations that are commonly encountered in everyday life. Reading competence can be defined from multiple perspectives: cognitive view; decoding, text-meaning construction, and assimilation with prior knowledge, developmental perspective; decoding and comprehension, and gear theory; reading purpose. Language competence is essentially acquired through practice and experience.

Richards \& Rodgers (2007) classify views of language into; structural view, functional view, and interactional view. Structural view is dealing with a system of structurally related elements for coding and meaning. Elements of this system are phonological units like phonemes, grammatical units like clauses, phrases, sentences, grammatical operations like adding, shifting, joining, or transforming elements. Lexical items are like function words and structure words. In order to use the language as its function, learners should be competent in this structural view. Being competent in these views, learners will practice to use the language in order to have skills in the language; receptive skills (listening and reading) and productive skills (speaking and writing). Hence, it will be for interaction as the context in which the language is used. To the context of this study, learners are not in the context of the language they learn. They need to be immersed in the context of the language learnt is used as they do in acquiring the first language. One of the possibilities that they might do is by reading a lot of reading materials which are interesting for them.

\section{Extensive Reading for Indonesian Learners in Developing Language Competency}

This section is based on theories discussed and studies relating to the benefit of extensive reading in Indonesia. The benefit of extensive reading has been proven by researchers and teachers. It can not only improve the students' reading ability, but it has also been shown to expand knowledge of vocabulary, raise the general level of a language testing, and improve fluency and accuracy in writing. Brown (2001) claims that extensive reading component in conjunction with others focused on reading instruction is highly warranted. Yamashita (2008) found that extensive reading improve the students' reading rate or reading strategy and the general language proficiency. Yamashita (2008) believes that extensive reading is also as the form of acquiring micro level linguistics.

Practicing extensive reading as reading activities by Indonesian EFL majoring in English based on the three studies will be desribed in this section. The first one is the experience based on the data gained on reading activities as a study conducted by Delfi \& Diah (2007). The data about the participant' experiences in reading show the stages faced by the partcipant in building her interest in reading. The study was from the perspectives of holistic education. The participant was a learner Riau University majoring in English. The participant has been able to read since five 
years old. She kept on doing reading for her education. Her interest in reading in the first language at earlier age reflects on reading English texts. The partcipant always read various reading materials; magazines, news paper, and course books. She began to develop her interest to read by reading teaching materials from the course books. She often visited library at the school age. She read course books and stories in the library. She has had a collection of stories since senior high school. She had been reading stories since she was a university student. Her interest in reading also improved her ability as an English department student. She always read all course books indicating her effort to increase her academic ability. She applied reading texts after learning reading strategies. She improved her academic ability by reading grammar-course books. The result of this study shows how reading outside of classroom develops her English competency. However, this study was not mainly about how extensive reading develops English competency.

Another study was a study conducted by Martini (2008) at Accounting Department, Padang State Polytechnic. The aim of the study was to find whether the implementation of extensive reading task successfully improved the students' reading motivation. The study found that the implementation of extensive reading task could successfully improve the students' reading motivation. Martini focused on doing extensive reading as task relating to the materials of the course in order to extend reading materials read by students outside of the classroom. She probably referred to some concepts of extensive reading offered by Bamford \& Day (1998, 2004). Martini suggested; (1) Teachers should motivate students to read a lot of reading materials, (2) Teachers should be creative in finding interesting reading materials, (3) Teachers should be a good model, (4) Teachers should give a lot of reading tasks which can be read at home, (5) Teachers should control the students' reading activities outside of the classroom by using written report.

The other context was a study conducted by Edy (2014). He studied the effectiveness of extensive reading on students' reading comprehension achievement and students' motivation at STAIN Curup, Indonesia. The study proves that students taught through extensive reading activity showed higher scores than those taught by conventional way; however, there is no interaction between students' motivation and extensive reading. The practice on extensive reading in this study was only for reading course in which the goal is for comprehension. Therefore, Sarwo Edy suggests make special course for extensive reading in order to enhance the students' reading skills and reading habit.

These studies indicate the need of a deep study on how Indonesian learners as EFL learners practiced extensive reading. Learner's interest in reading in the first language at earlier age reflects on reading English texts (Delfi \& Diah, 2007). It indicates that the participant always reads outside of the classroom. Her interest in reading improved her ability as an English department student. The result of this study shows how reading outside of classroom develops her English competency. It is possible to introduce learners to extensive reading activities in teaching English, specifically reading conducted by Martini (2008) and Edy (2014). They found the use of extensive reading in which the students' ability improved by applying 
extensive reading. Martini (2008) suggests the implementation of extensive reading in terms of reading interesting and lot of reading materials and teachers to be a good model while Edy (2014) suggests make special course for extensive reading in order to enhance the students' reading skills and reading habit. It needs to be considered for learners' English competency.

These studies show the contributions of extensive reading for EFL learners. The contributions are in terms of The review shows that the contribution of extensive reading is in terms of the context of Indonesian EFL learners, learning language, and characteristics and the benefit of extensive reading in the Indonesian EFL Learners' experiences. This review is expected to be appropriate to the context of Indonesian EFL learners; characteristics and the benefit of extensive reading meet the Indonesian EFL Learners' experiences. Since English in Indonesian is as a foreign language, learners do not acquire the language from speech. However, a learner who was not introduced in childhood has practiced extensive reading since childhood as a study conducted by Delfi \& Diah (2007). It means that experiences in extensive reading are personal; every learner faces different experiences. Besides, it shows that the learners treated extensive reading also affect on their English competency as a study conducted by Martini (2008) and Edy (2014).

These contexts show how extensive reading contributes to the language learning for language competency. The more the learners read, the more they acquire the language, and the more they acquire the language, the more they develop their language competency. It is as the reflection of Krashen's Input Hypothesis theory indicating $\mathrm{i}+1$. It means that the learners will know more than what they have known if they do extensive reading. It indicates that they acquire the language based on the text they read. Their understanding to the texts develops their prior knowledge that makes them confident to read the following texts. What they do as the practice of extensive reading indicates the characteristics of extensive reading as Bamford \& Day $(1998,2004)$. If learners do extensive reading as its characteristics, they will gain the benefit. It develops the language competency. This process shows how extensive reading contributes to English competency. Hopefully, this review supports the study designed.

\section{Conclusions}

This article is based on literature review for a study "a Case Study on Two Indonesian Learners' Extensive Reading in English Experiences towards Developing Reading Competency." This article aims to describe how extensive reading contributes to English competency. The review shows that the contribution of extensive reading is in terms of the context of Indonesian EFL learners, learning language for Indonesian EFL learners, and characteristics and the benefit of extensive reading meet the Indonesian EFL Learners' reading experiences. The more the learners read, the more they acquire the language, and the more they acquire the language, the more they develop their language competency. This process shows how extensive reading contributes to English competency. This review is expected to be meaningful for the study designed 


\section{References}

Ahmed, RAI \& Rajab, H. (2015). Enhancing Elementary Level EFL Students' Reading Comprehension and Writing Skills through Extensiev Reading Enrichment Program. International Journal of English Language Education, 3(2), 2015.

Bamford, J. \& Day, R. R. (1998). Extensive Reading Activities in the Second Language Classroom. UK: Cambridge University Press

Bamford, J. \& Day, R. R. (2004). Extensive Reading Activities for Teaching Language. UK: Cambridge University Press

Brown, D. H. (2007). Principles in Language Learning and Teaching. New York: Pearson Education Inc.

Byrness, P. \& Wasik, A. B. (2009). Language and Literacy Development. New York: The Guilford

Chen et al. (2013). The Effects of Extensive Reading via E-Books on Tertiary Level EFL Students' Reading Attitude, Reading Comprehension and Vocabulary. TOJET: The Turkish Online Journal of Educational Technology, 12(2), 2013

Delfi, S. \& Diah, S., F. (2007). Reading Activities from the Perspectives of Holistic Education. Unpublished Researach Report, Riau University

Edy, S. (2014). The Effectiveness of Extensive Reading on Students' Reading Comprehension Achievement as Observed from Students' Motivation. Jurnal Pendidikan Humaniora. 2(2), 2014

Ellis, R. (2003). Second Language Acquisition. Oxford: Oxford University Press

Ellis, R. (2012). Understanding Second Language Acquisition. Oxford: Oxford University Press

Gass, S. \& Selinker, L. (1994). Second Language Acquisition; An Introduction. New Jersey: Lawrence Erlbaum Association, Inc.

Guo, Siao-cing. (2012). Using Authentic Materials for Extensive Reading to Promote English Proficiency. English Language Teaching, 5(8), 2012.

Harmer, Jeremy. (2007). How to Teach English. England: Pearson Education

Hedgcock, J.S. \& Ferris, D. R. (2009). Teaching Readers of English, Students, Texts, and Contexts, New York: Routledge

Hedge, T. (2007). Teaching and Learning in the Language Classroom. Oxford: Oxford University Press

Jang, H., Kang, M., Kim, Y. (2015). The Effect of English Extensive Reading Activities on Students Reading Proficiency and Reading Motivation. Advanced Science and Technology Letters, Vol. 92.

Krashen, S. (1981). Principles in Second Language Acquisition. Oxford: Pergamon Press

Krashen, S. (1982). Second Language Acquisition and Second Language Learning. Oxford: Pergamon Press

Krashen, S.D. (1985). The Input Hypothesis. Harlow: Longman. 
Lee, Sy-ying \& Hsu, Ying-ying. (2009). Determining the Crucial Characteristics of Extensive Reading Program; the Impact of Extensive Reading on EFL Writing. International Journal of Foreign Language Teaching, 5 (1), 12-20.

Lightbown, M. P. \& Spada, N. (2011). How Languages are Learned". Oxford: Oxford University Press.

Pigada, M. \& Schmitt, N. (2006). Vocabulary Acquisition from Extensive Reading; A Case Study. Reading in a Foreign Language, 18(1), 2006.

Martini. (2008). The Implementation of Extensive Reading Task to Improve Student's Reading Motivation at Accounting Department, Padang State Polytechnic. Jurnal Akuntansi \& Manajemen, 3(1), 2008

Mermelstein, D.A. (2014). Improving EFL Learners' Reading Levels through Extensive Reading. The Reading Matrix, 14(3), 2014.

Nwabudike, Cristopher Efiziafa \& Anaso, G. (2013). The Effects of Extensive Reading on Some ESL Learners' Vocabulary Development: A Case Study of Nigerian-TurkishInternational Colleges, Kano. International Journal of Humanities and Social Science Invention, 2(4), April. 2013, PP.34-42.

Richards, JC. \& Rodgers, TS. (2007). Approaches and Methods in Language Teaching. New York: Cambridge University Press.

Tukan, P. (2007). Mahir Berbahasa Indonesia. Jakarta: Yudistira

Wang, Y. (2011). Comprehensible Input through Extensive Reading: Problems in English Language Teaching in China. Asian EFL Journal, Vol. 53, 2011

Yamashita, J. (2008). Extensive Reading and Development of Different Aspects of L2 Proficiency. ScienceDirect, System 36 (2008) 661-672. doi:10.1016/j.system.2008.04.003

Yamat, Hamidah. (2012). Revisiting English Language Learning among Malaysian Children. Asian Social Science, 10(3), 2012. 